九州大学学術情報リポジトリ

Kyushu University Institutional Repository

\title{
Fertility Status of Bangladesh Soils -A Review
}

Moslehuddin, Abu Zofar Md.

Laboratory of Soils, Faculty of Agriculture, Kyushu University

Salma, Laizoo

Laboratory of Soils, Faculty of Agriculture, Kyushu University

Egashira, Kazuhiko

Laboratory of Soils, Faculty of Agriculture, Kyushu University

https://doi.org/10.5109/24152

出版情報：九州大学大学院農学研究院紀要. 41 (3/4)，pp.257-267，1997-03. Kyushu University バージョン：

権利関係 : 


\title{
Fertility Status of Bangladesh Soils -A Review
}

\author{
Abu Zofar Md. Moslehuddin, Salma Laizoo \\ and Kazuhiko Egashira \\ Laboratory of Soils, Faculty of Agriculture, Kyushu University, \\ Fukuoka 812-81, Japan \\ (Received November 29, 1996; Accepted December 17, 1996)
}

\begin{abstract}
Fertility status of Bangladesh soils was critically evaluated by reviewing the studies which have been carried out in universities and research institutes of Bangladesh. A Imost all upland soils are low in organic matter and deficient in N. A vailability of $\mathrm{P}$ to the crops is a problem mainly in calcareous soils of Ganges floodplain and acidic soils of terrace and hill areas. Status of $\mathrm{K}$ is not a great problem in floodplain areas, but terrace and piedmont soils are not capable of supplying enough $\mathrm{K}$ to the crops. Although $\mathrm{P}$ and $\mathrm{K}$ deficiencies are not severe, addition of these two nutrients is a must for getting higher yield.

Paddy soils remain under water during growing period which causes unavailability of $S$ and $\mathrm{Zn}$ for rice crops. Other dryland crops also face the problem of $\mathrm{S}$ and $\mathrm{Zn}$ deficiencies in many areas of Bangladesh. Boron was reported to be deficient in some regions. Magnesium deficiency was found in the coarse-textured soils of Old Himalayan piedmont plain, Brown hill soils and Grey floodplain soils of the northern part of the country. The Ca reserve of many floodplain soils is depleting due to decalcification process and deficiency of Ca is probable in near future. Deficiencies of $\mathrm{Cu}$ and $\mathrm{Mn}$ were reported but very rare. The overall fertility status is not satisfactory; need for fertility conservation is stressed.
\end{abstract}

\section{INTRODUCTION}

Bangladesh is situated within $20^{\circ} 25^{\prime}$ to $26^{\circ} 38^{\prime} \mathrm{N}$ latitudinal and $88^{\circ} 01^{\prime}$ to $92^{\circ} 41^{\prime} \mathrm{E}$ longitudinal ranges having a total land area of about $144,000 \mathrm{~km}^{2}$, including $8,300 \mathrm{~km}$ " water bodies. A net cropped area of $91,300 \mathrm{~km}$ " occupies more than $60 \%$ of the total land mass (Ahsan and Karim, 1988). The area under paddy cultivation is about $80 \%$ of the cropped area.

The climate of Bangladesh is tropical to subtropical monsoon, with most rainfall occurring between June and September (Ahsan and Karim, 1988). Mean annual rainfall is 2,200 $\mathrm{mm}$, varying from $1,250 \mathrm{~mm}$ in the west to $5,000 \mathrm{~mm}$ in the northeast. Mean annual temperature is $26{ }^{\circ} \mathrm{C}$ while mean monthly temperature varies from $18{ }^{\circ} \mathrm{C}$ in January to $30^{\circ} \mathrm{C}$ during April and May.

There are three cropping seasons in Bangladesh: early kharif (April to June), late kharif (July to September), and rabi (October to March) (Ahsan and Karim, 1988). The early kharif season is characterized by the highest temperature and evaporation with $20 \%$ of the annual rainfall occurring in this season. Main crops are aus rice, jute, and early summer vegetables. In the late kharif season, $80 \%$ of the total rainfall occurs. Flooding is very common, and one-third of the land remains under water. Main crops are aman rice and summer vegetables. The rabi is a dry and cool season with almost no rain. Main crops are boro rice, wheat, maize, pulses, oilseeds, groundnut, spices, and a wide variety of winter vegetables. 
The soils of Bangladesh have been formed from different kinds of parent materials and spread over three major physiographic units: (i) Northern and eastern hills of Tertiary formations, covering $12 \%$ of the total area; (ii) Pleistocene terraces of the Madhupur and Barind tracts, covering $8 \%$ of the total area; and (iii) Recent floodplains. Recent floodplains mainly comprise alluvial sediments of the Ganges, Brahmaputra, and Meghna river systems, occupying $80 \%$ of the country and can be divided into piedmont alluvial plains, meander floodplains, basin areas, estuarine floodplains, tidal floodplains, and sandy beaches (Saheed, 1984).

Soils are classified into 21 general soil types (previously 17 soil types) on the basis of formation and appearance of the soils according to the Bangladesh soil classification system (Hussain, 1992). This is a non-technical grouping of soils made originally to enable non-specialists to make use of technical soil information generated through the reconnaissance soil survey works (SRDI Staff, 1965-1977).

The whole of Bangladesh is divided into 30 agroecological regions on the basis of physiography, soil, depth and duration of seasonal flooding, and climate (FAO-UNDP, 1988). The agroecological environment is identical within one region (Hussain, 1992).

Agriculture is the mainstay of the economy of Bangladesh. It contributes to over 50\% of the gross domestic product and provides employment for $74 \%$ of the labor force (Ahsan and Karim, 1988). However, the present agricultural production is not sufficient for the 120 million population of the country which is increasing at the rate of about $2.5 \%$ annually. The yield of almost all crops is very low in Bangladesh in respect with some other developed countries. This is due to a number of reasons in which soil is a dominating factor.

Research on the fertility of Bangladesh soils was initiated in 1911 (Islam, 1992). Until early fifties, the studies were confined to the use of mostly organic manure like bonemeal, green manure, mustard oil cake, cowdung, compost and so on. Lime and some chemical fertilizers were also used. Use of commercial fertilizers in Bangladesh agriculture started in 1951 with the import of ammonium sulfate (Islam et al., 1992). The use of urea and triple superphosphate began in 1957-58 and that of muriate of potash in 1960. With the introduction of these chemical fertilizers, researchers used these fertilizers in their experiments with a view to observe the effects of addition of $\mathrm{N}, \mathrm{P}$, and $\mathrm{K}$ on the yield of different crops.

Until 1950, farmers did not need to use any chemical fertilizers to grow crops. In those periods farmers had a lot of land to cultivate and lots of cowdung and crop residues to apply into soil, as fuel problem was not developed at all. They could fallow the land to conserve fertility, as the population pressure on the soil was not high. Addition of only crop residues and cowdung was enough to grow local varieties of different crops. The yield was not so high, but the production was enough to feed the population.

As the time passed, population of the country increased and consequently, the pressure on soil increased. The land owned by each farmer decreased. The intensity of farming was increased to feed the increasing population. Now, farmers have to grow crops all round the year with no chance of keeping the land fallow in order to conserve the fertility and are even not able to allow some time for growing green manure crops. To cook food they have to use all of the crop residues and cowdung as fuel. 
To get higher yield, high-yielding varieties (HYV) of different crops were introduced during late sixties to early seventies. Intensive cropping with HYV mines a large amount of nutrients from the soil. Fertility of soils started to be depleted. Soils have been becoming barren day by day and deficiency of different nutrients has been developing one by one.

Until 1980, farmers used only NPK-fertilizers but at present, they must apply at least five kinds of chemical fertilizers including $\mathrm{S}$ and $\mathrm{Zn}$ to grow paddy crops. Following $\mathrm{Zn}$ and $\mathrm{S}$, addition of $\mathrm{B}, \mathrm{Mg}, \mathrm{Mn}, \mathrm{Cu}$ or $\mathrm{Ca}$ is needed in some soils (Islam, 1992; Islam et al., 1992). The situation of other crops are almost similar to paddy. Farmers' economical condition is not good enough to apply so much fertilizer.

From the above discussion, it is obvious that fertility status of Bangladesh soils has been worsening day by day. Most of the research papers on the fertility status are limited in distribution and not available to scientists even within the country. In the present paper, we critically reviewed the present fertility status of surface layer of Bangladesh soils which may be useful to students, researchers, extension workers, and local and international planners.

\section{FERTILITY STATUS OF SOIL}

\section{Organic matter}

Organic matter is the storehouse of all the plant nutrients in the soil. It is the major source of two important mineral elements of $\mathrm{P}$ and $\mathrm{S}$, and essentially the sole source of $\mathrm{N}$. It is equally important in improving soil structural conditions, water and nutrient holding capacity, and microbial activities for successful cultivation.

In general, the organic matter content of Bangladesh soils is low. Bhuiya (1987) reported the organic matter contents of 17 soil series, each from 17 general soil types of Bangladesh (Table 1). According to him, Peat had the highest $(35.37 \%)$ organic matter content followed by Acid basin clays (5.20\%) and Acid sulphate soils (3.46\%). But, these soils are not agriculturally important, as they have some constraints to crop production. Among the remaining 14 soil series, only 4 soil series had more than $2 \%$ organic matter while other 10 soil series had below $2 \%$. The overall organic matter content is usually low in the agriculturally important soils in Bangladesh. Islam et al. (1992) found that organic matter ranged from 0.6 to $1.7 \%$ in 29 soil series from different regions of the country. Islam (1990) opined that at least $2 \%$ organic matter should be present in the soil for successful crop production. But, he observed that $90 \%$ soils of Bangladesh contained 0.5$1.0 \%$ organic matter.

Karim et al. (1995) reported that addition of organic residues increased the organic matter content to the level of 1.1 to $1.3 \%$ from the initial level of $0.7 \%$ in the Shallow redbrown terrace soil by the annual application of $2.0 \mathrm{Mg} /$ ha of air-dry rice straw, $7.5 \mathrm{Mg} / \mathrm{ha}$ of fresh ipilipil leaves, $25 \mathrm{Mg} / \mathrm{ha}$ of compost, or $25 \mathrm{Mg} / \mathrm{ha}$ of fresh cowdung under the ricewheat cropping rotation. Due to rapid decomposition rate, the organic matter content did not increase more, but the annual addition of organic residues increased the yield of both 
Table 1. Organic matter contents of Bangladesh soils.*

\begin{tabular}{llc}
\hline General soil type & Soil series & Organic matter (\%) \\
\hline Peat & Satla & 35.37 \\
Acid basin clays & Chakla & 5.20 \\
Acid sulphate soils & Bhadar Khali & 3.46 \\
Black terai soils & Lakhipur & 2.80 \\
Deep red-brown terrace soils & Tejgaon & 2.44 \\
Grey floodplain soils & Sabhar Bazar & 2.40 \\
Non-calcareous dark grey floodplain soils & Lokdeo & 2.18 \\
Calcareous dark grey floodplain soils & Ghior & 1.89 \\
Shallow red-brown terrace soils & Gerua & 1.85 \\
Brown mottled terrace soils & Noadda & 1.82 \\
Calcareous alluvium & Ramgati & 1.68 \\
Grey terrace soils & Chhiata & 1.47 \\
Brown hill soils & Kulaura & 1.44 \\
Calcareous brown floodplain soils & Gopalpur & 1.26 \\
Non-calcareous brown floodplain soils & Pirgachha & 1.16 \\
Grey piedmont soils & Pritimpasa & 1.11 \\
Non-calcareous alluvium & & 0.99 \\
\hline
\end{tabular}

*Source: Bhuiya (1987)

crops. Among the different organic residues, compost made of rice straw and cowdung was found to be most effective.

The organic matter status of Bangladesh soils is not only poor but also becoming worse day by day. Miah (1993) reported the 9 to $46 \%$ depletion of soil organic matter in different regions of Bangladesh over a period of 20 years from 1970 to 1990.

There are several reasons behind the low organic matter content of Bangladesh soils. The main reason is lack of organic recycling through addition of crop residues, animal waste, and other organic manures. Due to the fuel scarcity, plant residues including shoots and even roots, and cowdung have been used as fuel. According to Bhuiya (1987), as a tropical monsoon climatic country plants in general grow luxuriantly in the summer season, but due to the high temperature and rainfall the organic matter added to soil in the form of biomass is decomposed rapidly. He also reported that due to the intensive cultivation, the soils were being disturbed vigorously through tillage operation like plowing, puddling, laddering and so on, leading to enhancement of decomposition of organic matter. Use of urea fertilizer, which is presently a main nitrogenous fertilizer in Bangladesh, may enhance microbial activities resulting in the decomposition of organic matter, as revealed from an incubation study in the laboratory (Hoque, 1983).

Low-lying areas of most floodplains have a good reserve of organic matter, higher than that in high land or medium-high land. These soils remain under water for a considerable period of time of a year. So, little decomposition of organic matter can occur. Moreover a large number of aquatic weeds grow which add organic matter to these soils (FAO-LJNDP, 1988). 


\section{Nitrogen}

Like other tropical and subtropical soils, Bangladesh soils have long been categorized as poor in soil fertility because of low N supplying capacity (Islam, 1983). Nitrogen is the most limiting factor in crop production. The pale green color of $\mathrm{N}$-deficient plants is the most common deficiency symptom exhibited by growing plants (Thompson and Troeh, 1978). The total $\mathrm{N}$ content of Bangladesh soils is in a range of 0.02 to $0.12 \%$ (Ahsan and Karim, 1988). Portch and Islam (1984) studied 63 soil samples from different regions of Bangladesh and found that $100 \%$ of them were deficient in $\mathrm{N}$ (Table 2). Islam et al. (1992) reported analytical data of.29 soil series; all had the $\mathrm{N}$ content below the critical level. Moslehuddin (1993) also found $\mathrm{N}$ deficiency in all of the 86 soil samples from Old Brahmaputra floodplain. Ali et al. (1981) reported very low $\mathrm{N}$ contents in most areas of Bangladesh.

Ali (1991) observed that the crop response to $\mathrm{N}$ was the highest among the all nutrients in Bangladesh. The extent of yield increase of rice by $\mathrm{N}$ application was up to $100 \%$, depending on the soil $\mathrm{N}$ status and kinds of rice crops grown. Yield increase was also observed in other crops such as jute, sugarcane, and tea. The reasons for the greatest response may be due to large $\mathrm{N}$ requirement of crops, inherent $\mathrm{N}$ deficiency in almost all soils of the country, low efficiency of $\mathrm{N}$ utilization by crops, and various mechanisms of $\mathrm{N}$ loss from wetland rice soils.

In Table 3, effects of $\mathrm{N}$ application on the yields of various crops are listed (Islam et al., 1992; BRRI, 1990, 1992). Other fertilizers than $\mathrm{N}$ were added in a optimum dose. Crop yields under both optimum $\mathrm{N}$ and zero $\mathrm{N}$ (control) are shown. Nitrogen application in a optimum dose increased yields of different crops significantly. The yield increase over control varied form $5 \%$ in transplanted aman rice to $227 \%$ in wheat.

Organic matter is the main source of N. In Bangladesh, the amount of organic matter

Table 2. Percentage of soil samples below the critical level (BCL) and above the critical level but below the optimum level (BO) for the various elements.*

\begin{tabular}{ccc}
\hline Element & BCL** & BO** \\
\hline $\mathbf{N}$ & $1100(75)$ & $0(150)$ \\
$\mathrm{P}$ & $41(12)$ & $35(26)$ \\
$\mathrm{K}$ & $75(0.2)$ & $17(0.4)$ \\
$\mathrm{Ca}$ & $14(2.0)$ & $14(4.0)$ \\
$\mathrm{Mg}$ & $21(0.8)$ & $25(2.0)$ \\
$\mathrm{S}$ & $68(12)$ & $14(26)$ \\
$\mathrm{Zn}$ & $79(2)$ & $14(4)$ \\
$\mathrm{Fe}$ & $0(20)$ & $8(40)$ \\
$\mathrm{Mn}$ & $14(5)$ & $16(10)$ \\
$\mathrm{c} \mathrm{u}$ & $0(1.0)$ & $19(3.0)$ \\
$\mathrm{B}$ & $14(0.2)$ & $60(0.5)$
\end{tabular}

* Source: Portch and Islam (1984).

** Critical and optimum levels were established by Agro Service International and are shown in the parenthesis; $\mathrm{Ca}, \mathrm{Mg}$, and $\mathrm{K}$ in mmol $(+) / 100 \mathrm{~mL}$ while other elements in $\mu \mathrm{g} / \mathrm{mL}$. 
Table 3. Effects of $\mathrm{N}$ and $\mathrm{S}$ application on the crop yield.*

\begin{tabular}{|c|c|c|c|c|c|c|c|c|c|c|}
\hline \multicolumn{7}{|c|}{ Treatments (kg/ha) } & \multirow[t]{2}{*}{ Crop/Variety } & Yield & $\begin{array}{l}\text { Control } \\
\text { yield }\end{array}$ & \multirow{2}{*}{$\begin{array}{l}\text { Status of } \\
\text { N/S on } \\
\text { control } \\
\text { yield } \\
\end{array}$} \\
\hline $\mathrm{N}$ & $\mathrm{P}_{2} \mathrm{O}_{5}$ & $\mathrm{~K}_{2} \mathrm{O}$ & $S$ & $\mathrm{Zn}$ & B & Mo & & \multicolumn{2}{|c|}{ (Mg/ha) } & \\
\hline 120 & 25 & 35 & 20 & 5 & - & - & Rice (Boro)/BR3 & $6.1(24)^{* *}$ & 4.9 & $\mathrm{~N}_{0}$ \\
\hline 80 & 25 & 35 & 20 & 5 & - & - & Rice (T. Aman)/BR1] & $4.0(5)$ & 3.8 & $\mathrm{~N}_{0}$ \\
\hline 120 & 80 & 80 & 40 & 5 & 2 & - & Wheat/Kanchan & $3.6(227)$ & 1.1 & $N_{0}$ \\
\hline 150 & 100 & 90 & 20 & 5 & 1 & - & Tomato/Man\& & $58.2(123)$ & 26.1 & $\mathrm{~N}_{0}$ \\
\hline 120 & 90 & 90 & 10 & 5 & - & & Chilli/Local & $6.9(73)$ & 4.0 & $\mathrm{~N}_{0}$ \\
\hline 120 & 90 & 80 & 30 & 5 & - & - & Turmeric/Local & $14.9(192)$ & 5.1 & $\mathrm{~N}_{0}$ \\
\hline 80 & 30 & 100 & 20 & & & & Sweet potato/Tripti & $65.2(52)$ & 42.9 & $N_{0}$ \\
\hline 90 & 60 & 90 & 10 & 3 & - & - & Millet/Bog-1 & $2.1(90)$ & 1.1 & $\mathrm{~N}_{0}$ \\
\hline 90 & 60 & 90 & 10 & 3 & - & - & Millet/Bog-1 & $2.9(107)$ & 1.4 & NO \\
\hline 120 & 25 & 35 & 20 & 5 & - & - & Rice (Boro)/BR3 & $6.1(56)$ & 3.9 & $\mathrm{~S}_{0}$ \\
\hline 80 & 25 & 35 & 20 & 5 & - & - & Rice (T. Aman)/BR11 & $4.0(18)$ & 3.4 & so \\
\hline 120 & 80 & 80 & 40 & 5 & 2 & - & Wheat/Kanchan & $3.6(33)$ & 2.7 & so \\
\hline 120 & 80 & 60 & 30 & 8 & 2 & - & Wheat/Kanchan & $4.7(34)$ & 3.5 & so \\
\hline 150 & 90 & 90 & 40 & 5 & - & - & Maize/Shuvra & $7.2(44)$ & 5.0 & so \\
\hline 150 & 90 & 90 & 20 & 5 & - & - & Maize/Barnali & $7.5(34)$ & 5.6 & so \\
\hline 80 & 30 & 100 & 20 & & & & Sweet potato/Tripti & $65.2(31)$ & 49.9 & $\mathrm{~S}_{0}$ \\
\hline 15 & 50 & 30 & 10 & 3 & - & - & Chickpea/Nabin & $1.7(80)$ & 0.95 & $\mathrm{~s}$, \\
\hline 110 & 70 & 80 & 40 & 8 & 1 & 1 & Cauliflower/Cl-96 & $33.1(139)$ & 13.8 & SO \\
\hline
\end{tabular}

* Source: Islam et al. (1992); BRRI (1990, 1992).

** Figures in the parenthesis indicate \% increase over the control yield.

is very low and is declining day by day, probably due to lack of proper attention to its improvement and maintenance. This is the reason why the $\mathrm{N}$ content is so low (Ali, 1991).

Soils of low-lying areas of most floodplains have a good amount of $\mathrm{N}$. One reason is that these soils have a good reserve of organic matter. Another reason is that nitrate- $\mathrm{N}$ accumulates in these soils through water movement from adjoining higher areas, where $\mathrm{N}$-fertilizers are applied to grow crops. Anyway, this excess $\mathrm{N}$ is a cause of the ecological hazard for the soil and environment (FAO-UNDP, 1988).

\section{Phosphorus}

Available P status of Bangladesh soils is in general poor. Portch and Islam (1984) reported that $41 \%$ of the soils of Bangladesh contained P below the critical level and 35\% of the soils contained $\mathrm{P}$ above the critical level but below the optimum level (Table 2). Bhuiyan (1988) reported that available $\mathrm{P}$ of Bangladesh soils ranged from 2 to $14 \mathrm{ppm}$ with a mean value of $12 \mathrm{ppm}$. Islam et al. (1992) reported that available P determined by the Agro Service International method varied from 2 to $18 \mathrm{ppm}$ in 29 soil series from all over the country; most of them were below the critical level (12 ppm). Egashira and Yasmin (1990) found that the total P contents of all of the 10 floodplain soils of Bangladesh were well above the critical level and that the soil of terrace area had the content just above the critical level, and they opined that total $\mathrm{P}$ was enough to sustain 
Table 4. Effects of $P, K, M g, Z n$, and $B$ application on the crop yield.*

\begin{tabular}{|c|c|c|c|c|c|c|c|c|c|c|}
\hline \multicolumn{7}{|c|}{ Treatments (kg/ ha) } & \multirow[t]{2}{*}{ Crop/Variety } & Yield & $\begin{array}{l}\text { Control } \\
\text { yield }\end{array}$ & \multirow{2}{*}{$\begin{array}{l}\text { Status of } \\
\mathrm{P} / \mathrm{K} / \mathrm{Mg} / \\
\mathrm{Zn} / \mathrm{B} \text { on } \\
\text { control } \\
\text { yield }\end{array}$} \\
\hline $\mathrm{N}$ & $\mathrm{P}_{\mathrm{z}} \mathrm{O}_{5}$ & $\mathrm{~K}_{2} \mathrm{O}$ & $\mathrm{S}$ & $B$ & $\mathrm{Zn}$ & $\mathrm{Mg}$ & & \multicolumn{2}{|c|}{ (Mg/ha) } & \\
\hline 120 & 25 & 35 & 20 & - & 5 & - & Rice (Boro)/BR3 & $6.1(13)^{* *}$ & 5.4 & $P_{0}$ \\
\hline 80 & 25 & 35 & 20 & - & 5 & - & Rice (T. Aman)/BR11 & $4.0(3)$ & 3.9 & $P_{0}$ \\
\hline 120 & 30 & 80 & 20 & - & 5 & - & Cotton/DPY1 & $2.0(18)$ & 1.9 & $P_{0}$ \\
\hline 120 & 25 & 35 & 20 & - & 5 & - & Rice (Boro)/BR3 & $6.1(15)$ & 5.3 & $\mathrm{~K}_{0}$ \\
\hline 80 & 25 & 35 & 20 & - & 5 & - & Rice (T. Aman)/ BR11 & $4.0(3)$ & 3.9 & $\mathrm{~K}_{0}$ \\
\hline 100 & 60 & 60 & 20 & - & 5 & - & Wheat/Kanchan & $4.4(83)$ & 2.4 & $\mathrm{~K}_{0}$ \\
\hline 150 & 100 & 160 & 20 & - & 5 & - & Potato/ Cardinal & $32.6(136)$ & 13.6 & $\mathrm{~K}_{0}$ \\
\hline 90 & 60 & 100 & - & - & - & & Sweet potato/ Tripti & $65.2(26)$ & 51.9 & $\mathrm{~K}_{0}$ \\
\hline 100 & 80 & 120 & 20 & 1 & 5 & 10 & Potato/ Cardinal & $29.0(34)$ & 21.7 & $\mathrm{Mg}_{0}$ \\
\hline 120 & 25 & 35 & 20 & - & 5 & - & Rice(Boro)/BR3 & $6.1(2)$ & 6.0 & $\mathrm{Zn}_{0}$ \\
\hline 150 & 90 & 90 & 30 & - & 5 & - & Maize/Barnali & $7.5(36)$ & 5.5 & $\mathrm{Zn}_{1}$ \\
\hline 80 & 25 & 35 & 20 & - & 5 & - & Rice (T. Aman)/BR11 & $4.0(11)$ & 3.6 & $\mathrm{Zn}$ \\
\hline 20 & 40 & 30 & 10 & - & 3 & - & Chickpea/Nabin & $1.7(34)$ & 1.3 & $\mathrm{Zn}_{v}$ \\
\hline 120 & 80 & 60 & 30 & 2 & 5 & - & Mustard/Nap-3 & $2.1(24)$ & 1.7 & $\mathrm{~B}_{0}$ \\
\hline
\end{tabular}

* Source: Islam et al. (1992).

** Figures in the parenthesis indicate \% increase over the control yield.

the normal growth of rice. The available $\mathrm{P}$ contents determined by the Olsen method by Egashira and Yasmin (1990) were above the critical level, depending on the clay content, in the soils of noncalcareous Tista and Brahmaputra floodplains and piedmont alluvial plains, whereas they were below the critical level in the soils of calcareous Ganges river floodplain and Barind tract.

The response of rice crops to $\mathrm{P}$ application was sporadic and the marked response has usually not been obtained in many of the wetland conditions of paddy soils because of the increase in $\mathrm{P}$ availability during water-logging. However, a sharp response of added $\mathrm{P}$ was reported in calcareous and acidic soils, because $\mathrm{P}$ is readily fixed in calcareous soils by reaction with $\mathrm{Ca}$ and in acidic soils by reaction with $\mathrm{Fe}$ and $\mathrm{Al}$. Yield increase up to $25 \%$ in rice, $16-34 \%$ in jute, and $35-38 \%$ in sugarcane was observed (Ali, 1991). Islam et al. (1992) reported 3\% yield increase in transplanted aman rice, 13\% increase in boro rice, and 18\% increase in cotton due to $\mathrm{P}$ application (Table 4). Mondal et al. (1991) reported that $\mathrm{P}$ application increased the yield of transplanted aman rice (BR11) by $17 \%$ in the Old Brahmaputra floodplain soil.

\section{Potassium}

Potassium is the third major nutrient deficient in most of Bangladesh soils. Previously, there was a general impression that Bangladesh soils have sufficient amounts of $\mathrm{K}$ and that there is no need for any potash fertilizer application. However, due to intensification of farming in recent years, well-spread responses to added potash fertilizer have been observed (Islam et al., 1985). 
Many studies have indicated that soils of floodplain areas have high $\mathrm{K}$ content, comparable with their mineral suite dominated by mica. Soils of terrace areas have the relatively low K content (Ahsan and Karim, 1988). Islam et al. (1992) observed that the exchangeable $\mathrm{K}$ content of 29 soil series from different areas of Bangladesh ranged from 0.07 to $4.7 \mathrm{cmol}(+) / \mathrm{kg}$ (= meq $/ 100 \mathrm{~g})$.

Islam (1992) reported that $\mathrm{K}$ status of most terrace and piedmont soils was low to medium. Tista and Surma Kushiara floodplains were also deficient in K. Based on the critical limit $(0.17 \mathrm{cmol}(+) / \mathrm{kg})$, about $50 \%$ of the cultivable areas of Bangladesh was found to be low in available $\mathrm{K}, 30 \%$ areas be medium $(0.18-0.34 \mathrm{cmol}(+) / \mathrm{kg})$, and the rest $20 \%$ areas (mostly in southern saline areas) be high $(0.35-0.50 \mathrm{cmol}(+) / \mathrm{kg})$ to very high $(>0.51 \mathrm{cmol}(+) / \mathrm{kg})$.

Ali (1991) reported a moderate response, up to $37 \%$ yield increase, of rice to $\mathrm{K}$ application in the hill and terrace soils, whereas a fairly good response was recorded in the piedmont and light-textured soils. He also suggested that whatever may be the extent of $\mathrm{K}$ response for rice crops, it is advisable to apply $\mathrm{K}$-fertilizer not only to prevent rapid depletion of soil $\mathrm{K}$ and to sustain crop productivity but also to maintain ionic balance in the soil. Application of K-fertilizer also increased the yields of jute, sugarcane, and tea. Islam et al. (1992) reported that application of $\mathrm{K}$ increased the yield by $3-15 \%$ in rice, by $83 \%$ in wheat, by $136 \%$ in potato, and by $26 \%$ in sweet potato (Table 4 ). Mondal et al. (1991) found 5\% yield increase of transplanted aman rice (BR11) in the Old Brahmaputra floodplain soil due to $\mathrm{K}$ application.

\section{Calcium, magnesium, and sulfur}

Calcium, $\mathrm{Mg}$, and $\mathrm{S}$ are called secondary nutrients. They are as important in plant nutrition as major nutrients, though plants do not usually require much of them. Many crops contain as much S as $\mathrm{P}$, sometime even more. Deficiencies of secondary nutrients can depress plant growth as much as deficiencies of major nutrients (Potash and Phosphate Institute, 1983).

Among the secondary nutrients, deficiency of $\mathrm{S}$ is the most serious in Bangladesh. Even it may have to be considered as the second most deficient nutrient, just after $\mathrm{N}$. Sulfur deficiency in Bangladesh soils is getting widespread and acute (Islam, 1983). Portch and Islam (1984) found that $68 \%$ of the -soils were below the critical level for S (Table 2). Bhuiyan (1991) reported that about 4 million ha of land is potentially deficient in S. Egashira and Yasmin (1991) studied 10 floodplain and 1 terrace soils, and found that total $\mathrm{S}$ was not enough to sustain the normal plant growth.

Sulfur deficiency, however, was not noticed in Bangladesh until early eighties. The main reasons behind its deficiency are considered to be: increased use of high analysis Sfree fertilizers over years; accelerated removal of $S$ by increasing level of production through HYV crops; prolonged submergence due to introduction of irrigated HYV rice; and application of higher rates of NPK-fertilizers (Islam, 1990).

The response of rice to $\mathrm{S}$ application is more pronounced than those to $\mathrm{P}$ and $\mathrm{K}$, as the reduced condition of wetland rice fields aggravates the $\mathrm{S}$ deficiency problem. Up to $43 \%$ yield increase was observed in rice (Ali, 1991). Effects of S application on the yields of various crops are shown in Table 3. Yield increase due to $\mathrm{S}$ application over control (no S) varied from $18 \%$ in transplanted aman to $139 \%$ in cauliflower. 
Previously, $\mathrm{Ca}$ and $\mathrm{Mg}$ were not at all a problem for crop production in Bangladesh soils. But, recent investigations revealed that hill and terrace soils are severely depleted of Ca and Mg (FAO-UNDP, 1971). Calcareous soils occurring in Ganges floodplain have a moderate to high exchangeable Ca reserve. But, decalcification and acidification processes have been going on even in young floodplain soils due to ferrolysis (Ahsan and Karim, 1988). The problem of $\mathrm{Ca}$ and $\mathrm{Mg}$ deficiencies is gradually emerging. Portch and Islam (1984) found that 14 and $21 \%$ of the soils were below the critical level for Ca and $\mathrm{Mg}$, respectively (Table 2). Magnesium was found to be deficient in the coarse-textured soils of Old Himalayan piedmont plain, Brown hill soils, and Grey floodplain soils of the northern part of the country (Islam et al., 1992). The tuber yield of potato was reported to be increased significantly by application of $\mathrm{Mg}$ (Table 4). The reason behind less prevalence of $\mathrm{Ca}$ deficiency in comparison to $\mathrm{Mg}$ deficiency may be that $\mathrm{Ca}$ is automatically added to the soil as a part of P- and S-fertilizers.

\section{Micronutrients}

Seven elements essential for plant growth but in a small amount are commonly referred to as micronutrients. They are $\mathrm{Zn}, \mathrm{Fe}, \mathrm{Mn}, \mathrm{Cu}, \mathrm{B}, \mathrm{Mo}$, and $\mathrm{Cl}$. Lack of any one of them in the soil can limit plant growth, even when all the other essential nutrients are present in adequate amounts (Potash and Phosphate Institute, 1983).

A mong the seven micronutrients, data on the status of $\mathrm{Cu}, \mathrm{Fe}, \mathrm{Mn}, \mathrm{Zn}$, and $\mathrm{B}$ of Bangladesh soils are available while the $\mathrm{Cl}$ and Mo status is yet to be studied. Of the five elements studied, Fe has never been reported to be deficient, whereas $\mathrm{Zn}$ and $\mathrm{B}$ are the most widely deficient and $\mathrm{Cu}$ and $\mathrm{Mn}$ are deficient in some areas (Islam et al., 1992). Status of the five micronutrients in the selected soils of Bangladesh is shown in Table 2 (Portch and Islam, 1984).

Zinc deficiency was observed in the studies by the workers of Bangladesh Rice Research Institute and Department of Agricultural Extension (BRRI, 1980; Mukhopadhayay et al., 1986). In general, Ganges floodplain and coastal saline soils and the area covered by HYV rice are deficient in $\mathrm{Zn}$. Yield increase in rice was reported as high as $27 \%$ due to $Z n$ application. This indicates that although $Z n$ requirement of a crop is very small, still its application cannot be overlooked particularly in the areas prone to Zn deficiency (Ali, 1991).

Islam et al. (1992) reported that the application of $\mathrm{Zn}$ increased the yield of boro rice, transplanted aman rice, maize, and chickpea by $2,11,36$, and $34 \%$, respectively, over control (no zinc) (Table 4). Mondal et al. (1991) found that in the Old Brahmaputra floodplain soil, application of $\mathrm{Zn}$ and B increased the yield of transplanted aman rice (BR11) by 11 and 8\%, respectively, but application of $\mathrm{Cu}$ and Mo had no such positive effect. In wheat, 21\% (Jahiruddin et al.,1995), and 30 and 55\% (Jahiruddin et al., 1992) yield increases were recorded due to application of B. Jahiruddin et al. (1992) got no response of wheat to applied $\mathrm{Cu}$ and Mo.

The reasons behind $\mathrm{Zn}$ deficiency in the soils of Bangladesh may be high soil $\mathrm{pH}$, presence of lime materials, soil submergence, and interaction with phosphate ion. Deficiencies of other micronutrients were caused mainly by intensive cultivation with HYV crops. 


\section{CONCLUDING REMARKS}

Now, it is important to sustain soil fertility. Before seeding, it should be ascertained which soil needs which fertilizer in what quantity by soil analysis. This information is not available to the farmers due to different constraints like lack of facilities, cost involved, and illiteracy of the farmers. Without this information, however, balanced fertilization is not possible, Nowadays, farmers use fertilizers to grow crops without knowing exactly the appropriate kinds and dosage. So, some nutrients may be added in excess, while some under the required level. Thus an imbalance could be created in soil chemical balance which is good for neither soil nor crops. Recently, Soil Resources Development Institute has been conducting semi-detailed survey and publishing the land and soil resources utilization guide for every thana (subdistrict) which contains the soil map (scale: 1:50,000) including fertility status and other information (SRDI Staff, 1985-1991). This will help the farmers to use the optimum kinds and dosage of fertilizers to their land.

Addition of organic matter is a must. Emphasis should be given on integration of organic manuring with application of chemical fertilizers. Organic recycling should be done by using compost, cowdung, green manure and so on by any means. More research is needed to develop strategy for sustaining soil fertility of Bangladesh soils.

Soil Science, Agronomy, and Horticulture Divisions of different research institutes and Soil Science Departments of the two universities of Bangladesh are mainly involved in applied research works. Basic research works are quite few, mainly due to lack of funds, facilities, and equipments, although the basic research is important. Status and behavior of different essential nutrients in soils should be studied in more depth to get a clear idea and to find out the directions on how to manage our soils.

\section{REFERENCES}

Ahsan, E. and Z. Karim 1988 Soil and management research on upland soils of Bangladesh. In: "Proceedings of the International Conference on the Management and Fertilization of Upland Soils in the Tropics and Subtropics", pp. 247-251

Ali, M. I. 1991 Crop response to different fertilizer elements in Bangladesh (rice, jute, sugarcane and tea). Paper presented in the conference on Production and Use of Multinutrient Fertilizer in Bangladesh, on 25-26 November, 1991 at Bangladesh Agricultural Research Council, Dhaka, Bangladesh

Ali, M. I., E. H. Bhuiya, M. M. Rahman and A. K. M. Habibullah 1981 Nutrient Status in Bangladesh Soils Evuluated through Soil Test and Pot Experiments Using Tracer Technique. Research Report No. 40, INA, Bangladesh.

Bhuiya, Z. H. 1987 Organic matter status and organic recycling in Bangladesh soils Resources and Conservation, 13:117-124

Bhuiyan, N. I. 1988 Co-ordinated Project on Potassium Studies: Progress Report (1987-88). Bangladesh Rice Research Institute, Gazipur, Bangladesh

Bhuiyan, N. I. 1991 Appropriate nutrient ratios for soils and crops of Bangladesh. Paper presented in the conference on Production and Use of Multinutrient Fertilizer in Bangladesh, on 25-26 November, 1991 at Bangladesh Agricultural Research Council, Dhaka, Bangladesh

BRRI 1980 Annual Report. Soil Chemistry Division, Bangladesh Rice Research Institute, Gazipur, Bangladesh BRRI 1990 Annual Internal Review. Bangladesh Rice Research Institute, Gazipur, Bangladesh BRRI 1992 Annual Internal Review. Bangladesh Rice Research Institute, Gazipur, Bangladesh Egashira, K. and M. Yasmin 1990 Total and available phosphorus of some floodplain soils of Bangladesh. Bull. Inst. Trop. Agr., Kyushu Univ., 13: 127-137 
Egashira, K. and M. Yasmin 1991 Sulfur status of Bangladesh floodplain soils. Bull. Inst. Trop. Agr., Kyushu Univ., 14: 15-23

FAO-UNDP 1971 Bangladesh: Soil Resources. Technical Report No. 3, FAO, Rome

FAO-UNDP 1988 Land Resources Appraisal of Bangladesh for Agricultural Development: Agroecological Regions of Bangladesh. Technical Report No. 2, FAO, Rome

Hoque, M. S. 1983 Experiences on Soil-related Problems to Crop Production in Bangladesh. Bangladesh Agricultural University, Mymensingh, Bangladesh

Hussain, M. S. 1992 Soil Classification with Special Reference to the Soils of Bangladesh. University of Dhaka, Dhaka, Bangladesh

Islam, A. 1992 Review of soil fertility research in Bangladesh. In "Proceedings of the Inter-Congress Conference of Commission IV of ISSS on Improving Soil Management for Intensive Cropping in the Tropics and Sub-Tropics”, ed. by M.S. Hussain, S.M.I. Huq, M.A. Iqbal and T.H. Khan, pp. 1-18

Islam, M. S. 1983 In "Soil Management in Agricultural Research in Bangladesh", Bangladesh Agricultural Research Council, Dhaka, Bangladesh, pp. 105-109

Islam, M. S. 1990 Soil characteristics and their effects on sulfur and zinc deficiency problems in Bangladesh. Paper presented at a workshop on Sulfur and Zinc Management of Soils and Crops and Balanced Fertilization in Bangladesh, on 10-11 April, 1990 at Dhaka, Bangladesh

Islam, M. S., S. Altamash, N. I. Sarker and K. M. Hossain 1985 Potassium responses in greenhouse and field studies in Bangladesh. In "Proceedings of the International Symposium on Potassium in Agricultural Soils", Soil Science Society of Bangladesh and Bangladesh Agricultural Research Council, pp. $70-89$

Islam. M. S., M. S. Amin and M. N. Anwar 1992 Integrated soil fertility management in Bangladesh. In "Proceedings of the Inter-Congress Conference of Commission IV of ISSS on Improving Soil Management for Intensive Cropping in the Tropics and Sub-Tropics”, ed. by M. S. Hussain, S. M. I. Huq, M. A. Iqbal and T. H. Khan, pp. 147-156

Jahiruddin, M., M. S. Ali, M. A. Hossain, M. U. Ahmed and M. M. Hoque 1995 Effect of boron on grain set, yield and some other parameters of wheat cultivars. Bangladesh J.Agr. Sci., 22:179-184

Jahiruddin, M., M. S. Hoque, A. K. M. M. Hoque and P. K. Roy 1992 Influence of boron, copper and molybdenum on gram formation in wheat. Crop Res., 5: 35-42

Karim, A. J .M. S., K. Egashira, Y. Yamada, J. Haider, and K. Nahar 1995 Long-term application of organic residues to improve soil properties and to increase crop yield in terrace soil of Bangladesh. J.Fac. Agr., Kyushu Univ., 39:149-165

Miah, M. M. U. 1993 Integrated nutrient management system for sustainable agricultural production in Bangladesh. Paper presented in the training course on Unified Methodology for Integrated Nutrient Management, on 10-16 July, 1993 at Bangladesh Rice Research Institute, Gazipur, Bangladesh

Mondal, M .H. R., M. Jahiruddin, M. M. Rahman and M. A. Hashem 1991 An investigation on nutrient requirements for BR11 rice in Old Brahmaputra Floodplain soil. Bangladesh J. Crop Sci., 2:23-30

Moslehuddin, A. Z. M. 1993 A Detailed Survey of the Fertility Status of Bangladesh Agricultural University Farm Soils. M. Sc. thesis, Soil Science Department of Bangladesh Agricultural University, Mymensingh, Bangladesh

Mukhopadhayay, D., M. Eunus and M. M. Huq 1986 Response of Major Crops to Balanced Fertilizer Application. Department of Agricultural Extension and Food and Agriculture Organization, Dhaka, Bangladesh

Portch, S. and M. S. Islam 1984 Nutrient status of some of the more important agricultural soils of Bangladesh. In "Proceedings of International Symposium on Soil Test Crop Response Studies", Bangladesh Agricultural Research Council and Soil Science Society of Bangladesh, pp. 97-106

Potash and Phosphate Institute 1983 Soil Fertility Manual. Potash and Phosphate Institute, Atlanta, USA

Saheed, S. M. 1984 Soils of Bangladesh. In: "Proceedings of International Symposium on Soil Test Crop Response Studies", Bangladesh Agricultural Research Council and Soil Science Society of Bangladesh, pp. $107-129$

SRDI Staff 1965-1977 Reconnaissance Soil Survey Reports of Bangladesh. Soil Resources Development Institute, Dhaka, Bangladesh

SRDI Staff 1985-1991 Land and Soil Resources Utilizations Guides. Soil Resources Development Institute, Dhaka, Bangladesh

Thompson, L. M. and F.R. Troeh 1978 Soils and Soil Fertility. McGraw-Hill Pub., New York, USA 